\title{
THE EFFECT OF MACRO ECONOMY ON SUKUK REQUESTS IN INDONESIA
}

\author{
Latifah $^{1}$; Nurmalasari ${ }^{2}$; Sri Dewi Ayu Safitri ${ }^{3}$ Taufik Baidawi $^{4}$ \\ Universitas Bina Sarana Informatika \\ Jl. Abdurrahman Shaleh no.18A Pontianak Tenggara 78124 Kalimantan Barat \\ E-mail : latifah.lat@bsi.ac.id \\ diterima: 1/12/2020; direvisi: 30/2/2021; diterbitkan: 26/3/2021
}

\begin{abstract}
The implication of the development of the banking world is the emergence of various types and forms of financial institutions, and one of them is Islamic Banking. The concept of the system applied by Islamic Banking is a form of profit sharing between the customer and the bank itself. This system does not take into account the system or can also be called a bank without interest. This study aims to analyze how the influence of the Per capita Deposit, Inflation and Gross Domestic Product (GDP) Interest Rates on demand for sukuk on Retail Sukuk products in Indonesia. The data used in this study are time series data using multiple regression analysis methods. The results showed that the regression coefficient value of -0.331 (negative) and a significant value $(0,000)$ was smaller than the significance level (0.05), indicating that the profit sharing ratio had a negative effect. Inflation produces a $t$ value of 4.972 and has a significant level of 0.000 where this value is significant to the significance of 0.05 and smaller than 0.05 . From the results of the $t$ test it can be concluded that inflation has a significant positive effect on predicting retail sukuk demand. GDP per capita produces a t value of 5,250 and has a significant level of demand for retail sukuk by 0.01 when compared to the predetermined degree of error of 0.05 . This variable is significant. From the results of the $t$ test it can be concluded that GDP per capita has a significant positive effect. GDP per capita has a positive and significant effect on predicting retail Sukuk demand. This shows that in the period 2012-2019 that positive GDP per capita increased from year to year became an indicator of the rate of economic growth
\end{abstract}

Keywords: influence of the Per capita, Deposit Inflation and Gross Domestic Product, Sukuk Requests In Indonesia

\section{INTRODUCTION}

Deposit interest rates have a positive and significant impact on demand for Sukuk in Indonesia. This is due to the economic downturn at this time so that people are more looking for profit. Deposit interest rates are a reference for Bank Indonesia, so deposit income tends to be constant and even changes are minimal every year. Sukuk uses a flooting with floor system, meaning that the compensation can increase if the reference level rises but the bias cannot decrease lower than the minimum limit. This is different from deposit rates which are very volatile. So that if people invest with deposits the benefits obtained will still be even possible to decline so that the conclusion will be the profit sharing ratio generated by Sukuk is still more profitable to see the current sluggish economic conditions.

Inflation has a significant positive effect on retail Sukuk demand. This means that the relationship between inflation and Sukuk demand is in the same direction, the higher the inflation, the demand for Sukuk increases because people will refrain from shopping but more save or buy investments that can be profitable. Especially Sukuk which incidentally has underlayying assets. The relationship of inflation with directional demand for Sukuk that occurred during the period 2012-2019, can be explained by the statement that inflation causes the real interest rate to fall so that investing in the money market is less profitable. As a 
result, people are looking for other alternatives that can provide more profitable returns. One of them is investing in the capital market or by buying Sukuk or Islamic bonds in the banking industry.

GDP per capita has a positive and significant effect on predicting retail Sukuk demand. This shows that in the 2012-2019 period that positive GDP per capita increased from year to year became an indicator of the rate of economic growth. For further research, researchers are expected to test other variables that can influence the demand for sukuk in Indonesia, because the more variables tested are expected to have an impact on economic improvement in Indonesia

\section{LITERATURE REVIEW}

Good economic growth is reflected by good macroeconomic variable conditions. Good macroeconomic conditions can reflect a good investment climate in a country. The development of investment activities today has experienced very rapid progress. This happened along with the increase in the level of public knowledge about how to invest optimally and supported by stable domestic economic conditions. Macroeconomic theory is one of the fields of study of economics that sees and analyzes economic activities prevailing in the country through a comprehensive analysis (Sukirno, 2013: 27) while according to Mankiw (2006) Macroeconomics is the study of the economy as a whole including income growth, changes price, and unemployment rate.

The developed economic system basically has a goal to realize the level of economic growth of humanity in the long run and also in order to maximize the level of welfare of mankind. In the Islamic view, economic activities that are suitable and recommended are through business activities and also investment.

Sukuk is a term derived from Arabic, which is from the word 'Sakk' with the plural form (plural) is 'Sukuk' which means a document or certificate. In medieval times, sukuk was commonly used by Muslim traders as a document that showed financial obligations arising from trade and other commercial activities (Hariyanto, 2016). Meanwhile, according to Dunil 2004: 43) Sukuk or commonly referred to as Sharia Bonds is one of the securities. Securities are securities, namely debt recognition instruments, commercial securities, shares, bonds, debt proof. The unit includes a collective investment mark, a futures contract for the securities and any derivatives of the securities.

According to Nafik (2009: 252256) Sukuk can be distinguished based on the type of contract used and based on the issuer or issuing agency. Based on the type of sukuk contract, it is divided into six types, namely:

The level of demand for retail state sukuk can be seen from the number (volume) of sukuk sold, i.e. sukuk demanded by investors in the secondary market. Trading volume can illustrate the strength between selling and buying interest in market transactions (Suharto, 2015 in Amaliyah, 2018).

According to Zulkhibri (2015), sukuk as a driver of the financial system must take place by modifying modest existing conventional products and maintaining the objectivity of other capitalist financial systems. Therefore, sukuk must be formed with the spirit of creating an Islamic financial system, which is in accordance with Islamic principles and achieves the goals of Islam itself, namely Maqashid Sharia.

Based on the issuer or issuing institution, sukuk can be divided into two types, namely (1) corporate sukuk (sukuk). Corporate sukuk are sukuk 
Jurnal Ilmiah Ekonomi dan Bísnis

Vol. 18. No.1,Maret 2020 : 74-83

EISSN : $2442-9813$

ISSN : $1829-9822$

issued by corporations or companies, both private and state-owned companies; (2) State sukuk (sovereign sukuk). Government-issued sukuk, in this case the Ministry of Finance of the Republic of Indonesia (Fasa, 2016: 7)The investment is important for Muslims. Investment is a person's activity in functioning wealth to obtain income or other benefits in the long run. Another understanding says investment can be interpreted as an action to develop the value of assets owned. Investment can be carried out in the real and financial sectors (Kholis, 2010).

Domestic macroeconomic stability is indispensable for the condition of existing securities instruments in the Indonesian Islamic capital market, especially Sukuk issuance, changes in macroeconomic conditions can have an impact on the Islamic capital market.

Macroeconomic environment is an environment outside the company that is able to influence the daily operations of the company. Macroeconomic environment studies the national economy as a whole such as consumers, the banking world, the government, and the business world. Macroeconomic environment that can directly affect company performance and stock performance.

Good macroeconomic conditions will affect the issuer's decision to issue Sukuk. As for previous studies Hannoeriadi \& Lubis (2017) with the title Effect of Macroeconomic Variables on the Growth of Corporate Sukuk in Indonesia, that the results of this study indicate that the variable money supply, industrial production index, and inflation have a positive (significant) effect on the growth of corporate Sukuk. The variable exchange rate, oil price, and profit sharing from mudharabah deposits have a negative (significant) effect on the growth of corporate Sukuk.
Arif \& sofawati (2019) with the title Effect of Macroeconomic Factors on the Total Value of Corporate Sukuk Emissions in Indonesia (January 2013December 2017) with the results of his research namely where inflation, the rupiah exchange rate and Bank Indonesia Syariah Certificate (SBIS) partially have an influence which is significant to the total value of corporate Sukuk emissions in Indonesia in the period January 2013December 2017 and simultaneously all independent variables significantly influence the total value of corporate Sukuk emissions in Indonesia in the January 2013-December 2017 period by $84.40 \%$.

Ardiansyah and Lubis (2017) examine the "Effect of Macroeconomic Variables on the Growth of Corporate Sukuk in Indonesia," indicating that inflation results have a partial effect on the growth of corporate Sukuk in Indonesia and is positive, stating that an increase in inflation causes people to choose to maintain the value of their money through purchases corporate Sukuk compared to holding money whose real value will continue to decline along with the increase in inflation. This means that if inflation increases, the total value of corporate Sukuk emissions will increase.

According to Altaleb, et al. (2016), by increasing funding sources from the issuance of sukuk, it can help companies and countries improve investment in many sectors such as agriculture, industry and consumption. In an effort to gain profits for the company, issuing sukuk can increase financial funds and use them to obtain new economic opportunities that are reflected as an increase in the company's ability to achieve higher levels of profit. Thus, an increase in investment in the real sector through sukuk can increase economic growth in a country. This is in line with the results of research by Echchabi (2016) who found that the 
issuance of sukuk has a positive effect in increasing economic growth.

Investment as a muamalah activity is also recommended in Islam. According to Wiyanti (2013), the concept of investment contains knowledge and spiritual norms as activities that are recommended in Islam as a precaution because no one knows about tomorrow. In addition, investment is part of mualamah activities which will be rewarded if it is intended for worship and in accordance with sharia principles (Pardiansyah, 2017).

Inflation is a general and continuous increase in the price of goods. Inflation is a monetary phenomenon where a decline in the value of the monetary calculation unit of a commodity. From this definition, there are three components that must be met in order to be said to have occurred inflation; that is, price increases, general in nature, and ongoing. (Rahardja and Manurung, 2008: 165).

Research conducted by Mustika Rini (2012) on Sharia Bonds (Sukuk) and Indonesian Macroeconomic Indicators: An Analysis of Vector Error Correction Models (VECM). This research model uses the Vector Error Correction Model (VECM) method. The results of the study found that in the short term the issuance of sukuk and Indonesian macroeconomic indicators namely economic growth, the money supply, inflation, open unemployment, and SBIS bonuses did not affect each other whereas in the long run sukuk issuance was positively influenced by economic growth and the money supply. The issuance of sukuk was also negatively affected by inflation, open unemployment, and SBIS bonuses.

Hannoeriadi (2016) conducted a study on the effect of macroeconomic variables on the growth of corporate sukuk in Indonesia. The results of the study stated that the JUB variable, industrial production index, and inflation had a positive effect on the growth of corporate sukuk

Research conducted by Mohammad Agus Khoirul Wafa (2010) on Analysis of Factors Affecting the Demand for Retail Sukuk-I (March 2009June 2010) using a regression analysis research model found that state sukuk prices are retail sukuk prices, bond prices retail, syariah bank profit-sharing, and interest rates have a significant influence on the level of demand for retail state sukuk in the March 2009-June 2010 period.

Research conducted by Rahman (2017) on macroeconomic factors that influence the issuance of sukuk and corporate bonds in Indonesia has the result that partially only export variables, the exchange rate, the $\mathrm{BI}$ rate and inflation have a significant influence on corporate sukuk. Corporate bonds are only significantly affected by exports, the exchange rate and the $\mathrm{BI}$ rate.

According to Zulkhibri (2015), sukuk as a driver of the financial system must take place by modifying modest existing conventional products and maintaining the objectivity of other capitalist financial systems. Therefore, sukuk must be formed with the spirit of creating an Islamic financial system, which is in accordance with Islamic principles and achieves the goals of Islam itself, namely Maqashid Sharia.

Based on the issuer or issuing institution, sukuk can be divided into two types, namely (1) corporate sukuk (sukuk). Corporate sukuk are sukuk issued by corporations or companies, both private and state-owned companies; (2) State sukuk (sovereign sukuk). Government-issued sukuk, in this case the Ministry of Finance of the Republic of Indonesia (Fasa, 2016: 7)The investment is important for Muslims. Investment is a person's activity in functioning wealth to obtain income or other benefits in the 
Jurnal Ilmiah Ekonomi dan Bísnis

Vol. 18. No.1,Maret 2020 : 74-83

EISSN : $2442-9813$

ISSN : : 1829-9822

long run. Another understanding says investment can be interpreted as an action to develop the value of assets owned. Investment can be carried out in the real and financial sectors (Kholis, 2010).

macroeconomic conditions will affect the issuer's decision to issue Sukuk. As for previous studies Hannoeriadi \& Lubis (2017) with the title Effect of Macroeconomic Variables on the Growth of Corporate Sukuk in Indonesia, that the results of this study indicate that the variable money supply, industrial production index, and inflation have a positive (significant) effect on the growth of corporate Sukuk. The variable exchange rate, oil price, and profit sharing from mudharabah deposits have a negative (significant) effect on the growth of corporate Sukuk.

Arif \& sofawati (2019) with the title Effect of Macroeconomic Factors on the Total Value of Corporate Sukuk Emissions in Indonesia (January 2013December 2017) with the results of his research namely where inflation, the rupiah exchange rate and Bank Indonesia Syariah Certificate (SBIS) partially have an influence which is significant to the total value of corporate Sukuk emissions in Indonesia in the period January 2013-December 2017 and simultaneously all independent variables significantly influence the total value of corporate Sukuk emissions in Indonesia in the January 2013-December 2017 period by $84.40 \%$.

Ardiansyah and Lubis (2017) examine the "Effect of Macroeconomic Variables on the Growth of Corporate Sukuk in Indonesia," indicating that inflation results have a partial effect on the growth of corporate Sukuk in Indonesia and is positive, stating that an increase in inflation causes people to choose to maintain the value of their money through purchases corporate Sukuk compared to holding money whose real value will continue to decline along with the increase in inflation. This means that if inflation increases, the total value of corporate Sukuk emissions will increase.

In this study, the macroeconomic variables used to see the effect of the Sukuk level in Indonesia are Deposits, Inflation and Gross Domestic Product (GDP) per capita. Sukuk are securities that contain financing contracts (contracts) based on sharia principles. These Sukuk are issued by institutions / institutions / organizations both private and government to investors (Sukuk holders). Sukuk requires the issuing party to pay income to investors in the form of profit sharing or margin or fees during the contract period. Issuers are obliged to repay investment funds to investors upon maturity (Ryandono, 2009: 350) in other words Sukuk is one of the investment instruments that attracts Muslim investors who want to invest according to sharia principles. Demand for Sukuk is relatively high each time Sukuk is issued.

According to Altaleb, et al. (2016), by increasing funding sources from the issuance of sukuk, it can help companies and countries improve investment in many sectors such as agriculture, industry and consumption. In an effort to gain profits for the company, issuing sukuk can increase financial funds and use them to obtain new economic opportunities that are reflected as an increase in the company's ability to achieve higher levels of profit. Thus, an increase in investment in the real sector through sukuk can increase economic growth in a country. This is in line with the results of research by Echchabi (2016) who found that the issuance of sukuk has a positive effect in increasing economic growth.

Investment as a muamalah activity is also recommended in Islam. According to Wiyanti (2013), the concept of investment contains knowledge and spiritual norms as activities that are 
recommended in Islam as a precaution because no one knows about tomorrow. In addition, investment is part of mualamah activities which will be rewarded if it is intended for worship and in accordance with sharia principles (Pardiansyah, 2017).

In Indonesia, one of the most popular investment instruments is deposit interest. Many people choose to invest in this bank product because it is considered quite safe. Deposits are a place for customers to invest in securities. Based on the law of the Republic of Indonesia Number 10 of 1998 concerning Islamic banking, deposits are deposits which withdrawals can only be made at a certain time based on the customer's deposit agreement with the bank.

Inflation is a general and continuous increase in the price of goods. Inflation is a monetary phenomenon where a decline in the value of the monetary calculation unit of a commodity. From this definition, there are three components that must be met in order to be said to have occurred inflation; that is, price increases, general in nature, and ongoing. (Rahardja and Manurung, 2008: 165).

Gross Domestic Product (GDP) is the value of goods and services produced by a country in a certain period. The GDP factor is calculated to represent the level of income or economic activity. This relates that the level of income reflects the ability of the community to save. Per capita income has a positive effect on demand for Sukuk in Indonesia. Related to the above is explained by research from Muhammad Syahid Abdullah (2016) which states that in the short and long term per capita income has a positive effect on demand for Sukuk in Indonesia. The increase in income per capita causes the community to experience an increase in income so that it can buy investments, especially retail Sukuk.

Research conducted by Mustika Rini (2012) on Sharia Bonds (Sukuk) and Indonesian Macroeconomic Indicators: An Analysis of Vector Error Correction Models (VECM). This research model uses the Vector Error Correction Model (VECM) method. The results of the study found that in the short term the issuance of sukuk and Indonesian macroeconomic indicators namely economic growth, the money supply, inflation, open unemployment, and SBIS bonuses did not affect each other whereas in the long run sukuk issuance was positively influenced by economic growth and the money supply. The issuance of sukuk was also negatively affected by inflation, open unemployment, and SBIS bonuses.

Hannoeriadi (2016) conducted a study on the effect of macroeconomic variables on the growth of corporate sukuk in Indonesia. The results of the study stated that the JUB variable, industrial production index, and inflation had a positive effect on the growth of corporate sukuk

Research conducted by Mohammad Agus Khoirul Wafa (2010) on Analysis of Factors Affecting the Demand for Retail Sukuk-I (March 2009June 2010) using a regression analysis research model found that state sukuk prices are retail sukuk prices, bond prices retail, syariah bank profit-sharing, and interest rates have a significant influence on the level of demand for retail state sukuk in the March 2009-June 2010 period.

Research conducted by Rahman (2017) on macroeconomic factors that influence the issuance of sukuk and corporate bonds in Indonesia has the result that partially only export variables, the exchange rate, the $\mathrm{BI}$ rate and inflation have a significant influence on corporate sukuk. Corporate bonds are 
Jurnal Ilmiah Ekonomi dan Bísnis

Vol. 18. No.1,Maret 2020 : 74-83

EISSN : $2442-9813$

ISSN : $1829-9822$

only significantly affected by exports, the exchange rate and the BI rate.

\section{METHODOLOGY}

In this study the analysis techniques and methods used are quantitative descriptive methods. The study uses a regression model consisting of more than one independent variable. The linear regression model has several basic assumptions that must be met to produce a good estimate, known as BLUE (Best Linear Unexpected Estimator). In this study, macroeconomic variables that become independent variables are interest rates on deposits, inflation and gross domestic income, which will later be seen as an effect on the demand for Sukuk in Indonesia.

Based on the problem formulation and theoretical framework that has been described previously, the research hypotheses that can be formulated are as follows:

$\mathrm{H} 1=$ There is an influence of the interest rate on the yield on retail Sukuk demand in Indonesia. H2 = Inflation has an influence on the demand for retail Sukuk in Indonesia. H3 = There is an effect of GDP per capita on demand for Sukuk in Indonesia

Data analysis will be performed using the method of multiple linear regression (linear multiple Regression), using the least square (ordinary leas Square). This method can measure and analyze the strength of the relationship between variables, showing the influence and direction of the relationship between the dependent variable; Indonesian retail Sukuk products, with independent variables; Deposits, Inflation, and Gross Domestic Revenue Interest Rates. Data processing is carried out with the help of SPSS 21.0 program.

Before a regression analysis is performed, the data must pass various tests, including data normality tests, multicollinity tests, heteroscedasticity tests and autocorrelation tests. After the research variables meet the requirements of classic assumptions, then regression analysis and hypothesis testing are performed. Hypothesis testing is done by testing the $t$ test, $\mathrm{f}$ test, and the coefficient of determination (R2). $T$ test is a test to see whether the independent variables individually affect the variables associated with the assumptions of other variables constant. The $F$ test is basically aimed at seeing whether all the independent variables in the model have a joint effect on the related variable or the dependent variable. The coefficient of determination (R2) essentially measures how far the model's ability to explain variations in related variables.

State Sukuk is now a sharia financial instrument that is in the middle of discussions, both within the country and abroad. The development of this instrument is one of the Indonesian government's strategies in creating APBN funding sources. State sukuk issuance to support the development of Islamic finance that is growing in Indonesia. The provision of Islamic financial instruments will certainly help the Islamic financial industry, both banks, insurance, pension institutions, financial institutions in developing their assets. State Sukuk can be an alternative investment for the Islamic finance industry. In its development, State sukuk can also be an instrument to maintain liquidity among Islamic financial institutions.

\section{RESULTS AND DISCUSSION}

Prior to the multiple linear regression analysis, this research has fulfilled the validity and reliability tests as well as the classic assumption test as a prerequisite before the Linear Regression and From the results of the classical tests that have been done, it can be concluded that the regression model in this study is 
feasible to be used because the regression model is free from the problem of data normality, multicollinity does not occur, there is no auto correlation, and heterocedasticity does not occur, then multiple linear estimation tests will be performed and interpreted in the following table.

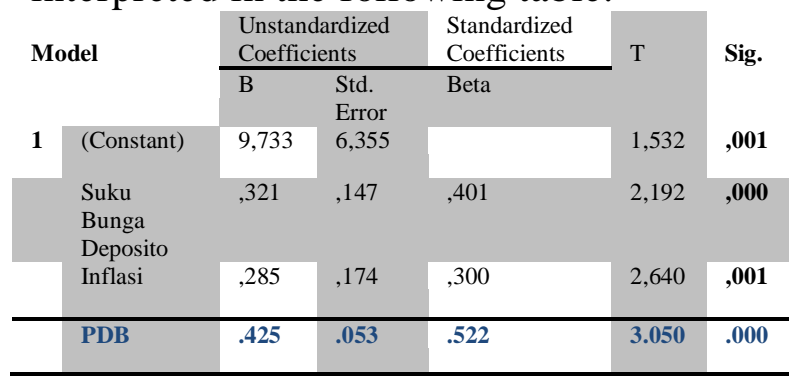

a. Dependent Variable: Sukuk

Source : Data Processing Results (2020)

Based on the linear regression output above, the multiple regression analysis model used in this study is formulated as follows.

Index $=9,733+0,321$ Interest Rates Deposits +0.285 inflation +0.425 GDP

The constant shows a figure of 9.733 which means that without the variable interest rates on deposits, inflation and GDP per capita has reached a value of 9.733 points. This indicates the influence of other variables besides the Deposit Interest Rate, inflation and GDP per capita. Other variables that are estimated to influence the retail Sukuk demand variables that have been examined include the Exchange Rate, the share price of the Sukuk, the Sukuk price and the volume of stock trading prices.

Deposit interest rates show the number 0.321 , each increase in deposit interest rates by $1 \%$ will reduce the demand for retail

\begin{tabular}{|c|c|c|c|c|c|c|c|c|c|}
\hline \multirow[b]{2}{*}{$\begin{array}{l}\mathrm{M} \\
\mathrm{o} \\
\mathrm{d} \\
\mathrm{e} \\
\mathrm{l}\end{array}$} & \multirow[b]{2}{*}{$\mathrm{R}$} & \multirow[b]{2}{*}{$\begin{array}{l}\mathrm{R} \\
\mathrm{Sq} \\
\text { ua } \\
\text { re }\end{array}$} & \multirow[b]{2}{*}{$\begin{array}{l}\text { Adj } \\
\text { ust } \\
\text { ed } \\
\text { R } \\
\text { Squ } \\
\text { are }\end{array}$} & \multirow{2}{*}{$\begin{array}{l}\text { Std. } \\
\text { of } \\
\text { Esti } \\
\text { mate }\end{array}$} & \multicolumn{5}{|c|}{ Change Statistics } \\
\hline & & & & & $\bar{R}$ & $\begin{array}{l}\text { F } \\
\text { Ch } \\
\text { an } \\
\text { ge }\end{array}$ & $\begin{array}{l}\mathrm{d} \\
\mathrm{f} \\
1\end{array}$ & $\begin{array}{l}d \\
f \\
2\end{array}$ & $\begin{array}{l}\text { Sig. } \\
\text { Cha } \\
\text { nge }\end{array}$ \\
\hline 1 & $\begin{array}{l}.8 \\
3 \\
5^{\text {a }}\end{array}$ & $\begin{array}{l}.7 \\
60\end{array}$ & $\begin{array}{l}.72 \\
0\end{array}$ & $\begin{array}{l}.138 \\
6\end{array}$ & .825 & $\begin{array}{l}23 \\
5.6 \\
43\end{array}$ & 3 & $\begin{array}{l}2 \\
8\end{array}$ & .000 \\
\hline
\end{tabular}

The amount of Adjusted R Square is 0.760 or $76 \%$. It can be concluded that the influence of Deposit Interest Rates, inflation and GDP per capita on demand for Sukuk in Indonesia is $76 \%$ while the rest is influenced by other variables not explained in this study such as exchange rates, interest rates, Sukuk prices, and etc. The coefficient number $(\mathrm{R})$ shows a value of 0.835 which indicates that the relationship between the independent variable and the dependent variable is strong and positive because it has a value of more than $0.5(\mathrm{R}>0.5)$ or $(0.835>0.5)$. And this relationship shows that if the dependent variable will go up, and vice versa if the free variable goes down then the dependent variable will go down.

The influence of Deposit Interest Rates, Inflation and GDP per capita on retail Sukuk demand is tested by test which aims to test the significance of the influence of one independent variable individually on the dependent variable. The results of testing with SPSS to predict retail Sukuk demand by using the variable Interest Rates on Deposits, Inflation and GDP per capita can be seen in the table:

\begin{tabular}{|c|c|c|c|c|c|c|}
\hline \multicolumn{2}{|c|}{ Model } & \multicolumn{2}{|c|}{$\begin{array}{l}\text { Unstandardized } \\
\text { Coefficients }\end{array}$} & \multirow{2}{*}{$\begin{array}{l}\text { Standardized } \\
\text { Coefficients } \\
\text { Beta }\end{array}$} & \multirow[t]{2}{*}{$\mathbf{T}$} & \multirow[t]{2}{*}{ Sig. } \\
\hline & & $\bar{B}$ & Std. & & & \\
\hline \multirow[t]{6}{*}{1} & (Constant) & .105 & .387 & & .265 & .000 \\
\hline & Suku & .039 & .028 & 225 & 2.654 & .000 \\
\hline & Bunga & & & & & \\
\hline & Deposito & & & & & \\
\hline & Inflasi & .179 & .036 & .722 & 4.972 & 000 \\
\hline & PDB & .376 & .049 & .651 & 5.250 & .001 \\
\hline
\end{tabular}

Dependent Variable: Sukuk

Source : Data Processing Results (2020)

Test the variable Deposit Interest Rate. The first hypothesis proposed is the variable interest rate on deposits. Judging from the regression coefficient which is 2,654 (Positive). Then the statement value in the first hypothesis is supported in this study, and the significant value $(0,000)$ is smaller than the significance level (0.05), so the statement in the second hypothesis is supported in this study. Thus, Hypothesis 1 (H1 accepted)

Test of Inflation variables. The 
Jurnal Ilmiah Ekonomi dan Bísnis

Vol. 18. No.1,Maret 2020 : 74-83

EISSN : $2442-9813$

ISSN : $1829-9822$

second hypothesis proposed is the Inflation variable that inflation has a positive influence on demand for Sukuk in Indonesia. Seen from the regression coefficient which is 0.4927 (Positive) and the significance value $(0.000)$ is smaller than the significance level (0.05), the statement in the second hypothesis is supported in this study. Thus, H2 Hypothesis is accepted.

Test of GDP per capita variable. The third hypothesis proposed is Per capita GDP has a positive effect on demand for Sukuk in Indonesia. Judging from the coefficient of regreni which is 5,250 (positive) and the significance value $(0.001)$ is smaller than the significance level (0.05), then the statement in the third hypothesis is supported in this study, Hypothesis (H3) is accepted.

\section{CONCLUSIONS AND SUGGESTION}

Deposit interest rates have a positive and significant impact on demand for Sukuk in Indonesia. This is due to the economic downturn at this time so that people are more looking for profit. Deposit interest rates are a reference for Bank Indonesia, so deposit income tends to be constant and even changes are minimal every year. Sukuk uses a flooting with floor system, meaning that the compensation can increase if the reference level rises but the bias cannot decrease lower than the minimum limit. This is different from deposit rates which are very volatile. So that if people invest with deposits the benefits obtained will still be even possible to decline so that the conclusion will be the profit sharing ratio generated by Sukuk is still more profitable to see the current sluggish economic conditions.

Inflation has a significant positive effect on retail Sukuk demand. This means that the relationship between inflation and Sukuk demand is in the same direction, the higher the inflation, the demand for Sukuk increases because people will refrain from shopping but more save or buy investments that can be profitable. Especially Sukuk which incidentally has underlayying assets. The relationship of inflation with directional demand for Sukuk that occurred during the period 2012-2019, can be explained by the statement that inflation causes the real interest rate to fall so that investing in the money market is less profitable. As a result, people are looking for other alternatives that can provide more profitable returns. One of them is investing in the capital market or by buying Sukuk or Islamic bonds in the banking industry.

GDP per capita has a positive and significant effect on predicting retail Sukuk demand. This shows that in the 2012-2019 period that positive GDP per capita increased from year to year became an indicator of the rate of economic growth. For further research, researchers are expected to test other variables that can influence the demand for sukuk in Indonesia, because the more variables tested are expected to have an impact on economic improvement in Indonesia.

\section{DAFTAR PUSTAKA}

Altaleb, Ghassan Salem dan Abdullah Y.A. 2016. Sovereign Islamic Sukuk and the Economic Development, A Case Study of Jordan. Europan Journal of Business and Management, Vol. 8, No. 32, hlm 115-118.

Ardiansyah, I. H., \& Lubis, D. (2017). Pengaruh Variabel Makroekonomi Terhadap Pertumbuhan Sukuk di Indonesia. Jurnal Al-Muzara'ah Vol.5, No.1, 51-67.

Dunil, Z., 2004, Kamus Istilah Perbankan Indonesia, Jakarta: Gramedia Pustaka Utama.

Echchabi, dkk. 2016. Does Sukuk Financing Promote Economic Growth? An Emphassis on the Major Issuing Countries. Turkish 
Journal of Islamic Economics, Vol. 3, No. 2, hlm 63-73.

Fasa, Muhammad Iqbal. (2016) "Sukuk : Teori dan Implementasinya", Li Falah Jurnal Studi Ekonomi dan Bisnis Islam Vol. 1 No. 1, hal. 80-94

Hariyanto, Eri. 2017. Evaluasi Kebijakan Penerbitan Sukuk Negara, Sebagai Instrumen Pembiayaan $A P B N$. Yogyakarta: Gava Media.

Ivan Hannoeriadi Ardiansyah dan lubis. 2017. Pengaruh Variabel Makroekonomi terhadap Pertumbuhan Sukuk Korporasi di Indonesia. Jurnal Al- Muzara'ah. Vol.5. No.1

Kholis, Nur. 2010. Sukuk: Instrumen Investasi yang Halal dan Menjanjikan. La_Riba Jurnal Ekonomi Islam, Vol. IV No. 2, Desember 2010

Manab A. dan Agus Eko S. 2016. Pengaruh Stabilitas Ekonomi Makro terhadap Penerbitan Sukuk Negara (di Indonesia, Malaysia, dan Brunei Darussalam). Tulungagung: Cahaya Abadi.

Mankiw, N Gregory dkk. (2008) "Pengantar Ekonomi Makro", Salemba Empat: Jakarta Nafik, Muhammad. (2009) "Bursa Efek dan Investasi Syariah", Serambi: Jakarta

Pardiansyah, E. (2017). Investasi dalam Perspektif Ekonomi Islam: Pendekatan Teoritis dan Empiris. Economica: Jurnal Ekonomi Islam, 8(2), 337-373.

Rahardja, Prathama dan Manurung, Mandala. 2008. Teori Ekonomi Makro. Edisi Keempat. Jakarta: Lembaga Penerbit FE UI

Rahman, Faizul dkk. (2016) "Pengaruh Harga Sukuk Negara Ritel Seri SR-005, Tingkat Inflasi dan BI Rate Terhadap Tingkat
Permintaan Sukuk Negara Ritel Seri SR-005", Jurnal Manajemen Vol. 8 No. 1, hal. 19-29

Rini, Mustika. 2012. Obligasi Syariah (Sukuk) dan Indikator Makroekonomi Indonesia, Sebuah Analisis Vector Error Correction Model. Iqtishodia Jurnal Ekonomi Islam Republika, Vol 2, No 1, hlm 87-104.

Sayed, Ola Al. 2013. Sukuk Risk: Analysis and Management. Europan Journal of Applied Social Sciences Research (EJASSR), No. 3, Vol. 1, hlm 67-76.

Sukirno, Sadono. (2013) "Makroekonomi Teori Pengantar". Raja Grafindo: Jakarta.

Wahyudi,Muhammad Arif dan shofawati (2019) Pengaruh Faktor Makroekonomi Terhadap Total Nilai Emisi Sukuk Korporasi Di Indonesia (Periode Januari 2013Desember 2017). Jurnal Ekonomi Syariah Teori dan Terapan Vol. 6 No. 3.

Wiyanti, D. (2013). Perspektif Hukum Islam terhadap Pasar Modal Syariah Sebagai Alternatif Investasi Bagi Investor. Jurnal Hukum IUS QUIA IUSTUM, 20(2), 234-254.

Zulkhibri, Muhamed. (2015) “A Synthesis of Theoretical and Empirical Research on Sukuk", Journal Borsa Istanbul Review diakses pada www.sciencedirect.com hal. 237-248 